\title{
大気摇らぎ環境下における高安定光送受信技術
}

\author{
安藤 俊行 ${ }^{1}$, 矢吹 麻菜 ${ }^{1}$, 原口 英介 ${ }^{2}$ \\ 1 三菱電機株式会社 情報技術総合研究所 ( ₹ 247-8501 神奈川県鎌倉市大船 5-1-1) \\ 2 三菱電機株式会社 鎌倉製作所 ( T 247-8520 神奈川県鎌倉市上町屋 325 番地)
}

\section{Highly Stable Optical Free-Space Transmission Technology Under Atmospheric Fluctuation}

\author{
Toshiyuki ANDO, ${ }^{1}$ Mana YABUKI, ${ }^{1}$ and Eisuke HARAGUCHI ${ }^{2}$ \\ ${ }^{1}$ Mitsubishi Electric Corporation, Information Technology R\&D Center, 5-1-1 Ofuna, Kamakura, Kanagawa 247-8501 \\ ${ }^{2}$ Mitsubishi Electric Corporation, Kamakura Works, 325 Kami-Machiya, Kamakura,Kanagawa 247-8520
}

(Received July 20, 2019)

\begin{abstract}
We present preliminary study on optical phased array technology aiming free-space optical communication for optical feeder link of High Throughput Satellite in the future. The propagation of non-Gaussian beams produced with optical phased array has been estimated less affected by atmospheric turbulence than a single Gaussian beam. 2-elements optical phased array has also demonstrated both beam pointing control and $5.6 \mathrm{Gbps}$ free-space optical communication.
\end{abstract}

Key Words: Optical phased array, Free-space optical communication, Atmospheric turbulence

1. はじめに

近年の観測衛星の大容量デー夕伝送や $100 \mathrm{Gbps}$ 超級 のブロードバンド衛星通信に適合する光衛星通信ネット ワークが望まれている，観測衛星のデータ伝送に向け欧 州ではデータ中継衛星 EDRS-A (European Data Relay System-A) が 2016 年に打上げられ†1, 運用フェーズに 入った ${ }^{\dagger 2}$. 通信方式・レートは波長 $1.06 \mu \mathrm{m}$, BPSK (Binary Phase Shift Keying) ホモダイン方式, 1.8 Gbps である1). 米 国では, LCRD (Laser Communication Relay Demonstration) により波長 $1.5 \mu \mathrm{m}$ 帯 DPSK(Differential Phase Shift Keying) 方式 $1.25 \mathrm{Gbps}$ の衛星間と衛星地上間の光通信デモが 2019 年に予定されている2). 国内でもJDRS (Japanese Data Relay System) が, 波長 $1.5 \mu \mathrm{m}$ 帯 DPSK (Differential Phase Shift Keying) 方式, 1.8 Gbps の通信実証実験に向 けて 2019 年に衛星の打上げを予定している3). さらに 衛星間の光デー夕伝送だけでなく, 衛星〜地上間光伝送 に向けた光地上局の開発も報告されている4 ${ }^{4}$. 大容量の 静止通信衛星に向けては, $70 \mathrm{Gbps} の \mathrm{Ka}-\mathrm{Sat} や 140 \mathrm{Gbps}$ の ViaSat-1 などの High Throughput Satellite: HTS が打上 げられ，ブロードバンド通信が展開されている，HTS
における現状の衛星 - 移動局間のユーザリンクと衛星 地上固定局間のフィーダリンクはともに, RF 通信であ るが, 将来的には RF 帯域不足が課題として考えられて おり5), この解決手段として光フィーダリンクによる広 帯域伝送が期待されている6). 以上より, 光衛星通信機 器に望まれる特性として, 複数方式に対応できる小型で 高感度特性, 衛星〜地上間での背景光抑圧性能や大気摇 らぎの補償特性が必要と考えられる。我々は, 波長 $1.06 / 1.5 \mu \mathrm{m}$ 帯の Dual 光受信方式の検討7)や, 追尾角度 センサ機能と光コヒーレント受信機能とを統合した高感 度で背景光抑圧特性の優れた受信フロントエンドを試作 した ${ }^{8-10)}$ 。また光コヒーレント送受信技術を用いた衛星 地上間の光通信システムの回線検討を実施した。ここで は，将来の光フィーダリンク適用に向けた光フェーズド アレイを用いた光空間通信技術の予備検討結果を報告す る.

\section{2. 衛星地上間光伝送時の大気伝搬特性}

衛星地上間の光伝送においては，大気伝搬に伴う，工 アロゾルや特定気体分子での散乱による損失に加え，大

\footnotetext{
$\dagger^{1}$ http://www.edrs-spacedatahighway.com/news/items/actionable-information

$\dagger^{2} \mathrm{http}$ ://www.edrs-spacedatahighway.com/news/items/first-image
} 
気分子の流れによる屈折率変動の影響によるビーム広が り角の増加や, 波面収差による受信光の結合効率の低下 が発生する. 衛星から地上へのダウンリンク光伝送にお いて，伝搬光が大気摇らぎにより受けた影響を，地上局 での受信光の波面変化として検出・補正する補償光学技 術の適用が進められている11)。しかしながら地上からの アップリンク光伝送において大気摇らぎの影響の衛星側 での補償は困難である。これは大気摇らぎの媒質層が地 上〜静止衛星間の距離 $36000 \mathrm{~km}$ に対して, 極めて地表 面近傍 (10 km 程度)に局在するためである。すなわち アップリンク伝送光は, 送出直後に大気摇らぎの影響を 受けて拡がって伝搬する結果, 衛星に到達する伝搬光サ イズが受信開口に比べて拡大するためである。アップリ ンク伝送における通信品質劣化の影響を受信側での信号 処理により低減する例が報告されているが12)，アップ リンク光そのものの伝送特性を改善した報告例は無い. 大気摇らぎ媒質中の伝搬光の空間モード解析によると, 高次モードが多く含まれるビームほど大気摇らぎによる 拡がりの影響を受けにくいことが知られている13)。こ の特性を利用し, 大気摇らぎの状態に応じたアップリン ク光のモードを制御することで，大気摇らぎによる拡が りの影響を低減した伝送の実現が期待できる.

\section{3. 光フェーズドアレイによる高次モード生成}

高次モード光の発生手段として, 複数の素子ビームを 空間配置し, 各素子の位相を制御する光フェーズドアレ イを用いることを考える. Fig. 1 に光フェーズドアレイ の構成図を示す。基準レーザー光(Master Oscillator Laser: MO Laser) をビームスプリッタで分岐して素子 ビームを形成，素子ビームごとに光位相制御と光増幅 (Optical Amp. )の後，ビームコンバイナで空間合成する. 位相検出器により取得した合成光の位相誤差を最小化す るように各素子ビームの位相をフィードバック制御する ことでコヒーレントビーム合成 (Coherent Beam Combine: $\mathrm{CBC})$ が可能である。一方, 各位相器に特定の分布を設 定して合成光パターンの制御も可能である.

Fig. 1 の実証系として, 光コンポーネントの入手性や アライメント容易性を考慮し, 基準レーザーから光増幅 器までを光ファイバ部品を接続して構成, 光増幅器出力 光をコリメート後に空間配置しビームコンバイナにより 空間合成する構成とした。

Fig. 2 に素子ビーム配置として 19 素子, 三角配列を

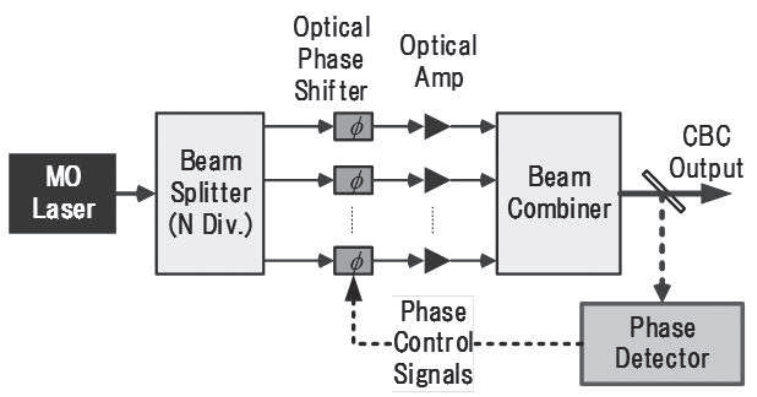

Fig. 1 Block diagram of an optical phased array transmitter. (a)

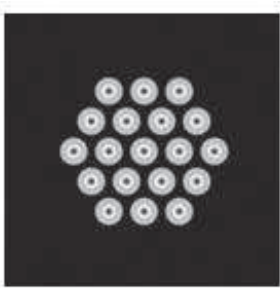

(b)
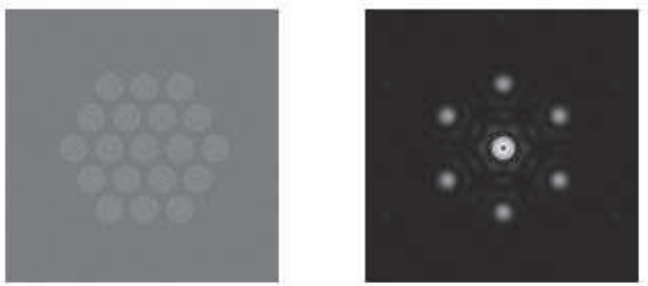

(c)
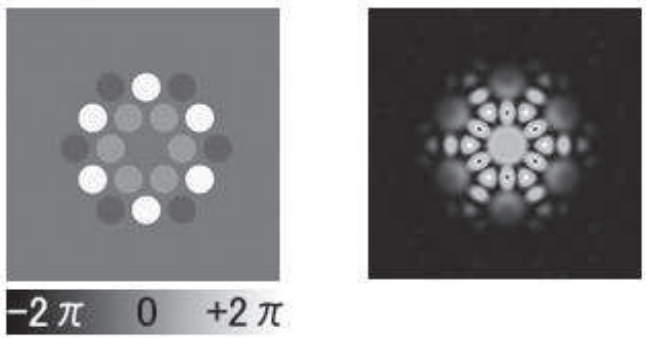

Fig. 2 Examples of calculation for Gaussian beam and higher-order spatial mode pattern. (a) Near field pattern (intensity), (b) Gaussian beam condition: left: near field pattern (phase); right: far field pattern (intensity), (c) Higher-order spatial mode condition: left: near field Pattern (phase); right: far field Pattern (intensity).

仮定した場合の位相分布と合成光の遠方界ビームパター ン計算例を示す。各素子ビームは理想的なコリメート状 態で指向角が一致した状態を仮定し，また素子ビームの $1 / e^{2}$ 径と素子ビーム間のピッチとの比を 0.9 に設定した 合成光の空間モードは各素子ビームの光位相器の設定に より行う。ここでは, Fig. 2(b)で示すような, 出射開口 面で等位相分布の Gaussian ビームパターン (左：近傍界， 右：遠方界)と, Fig. 2(c)で示すような出射開口面で同 心円状の位相分布の高次モードビーム (左：近傍界, 右： 遠方界)とを設定して計算した。

\section{4. 高次モード光の大気摇らぎ伝搬計算}

高次モードビームの大気摇らぎ媒質中の光の伝搬特性 を計算した. Fresnel 伝搬に基づく光の自由空間伝搬を 前提とし，大気摇らぎの影響は，伝送方向に沿って分割 した各層に位相マスクとして挿入した。位相マスクは大 気構造定数により設定した。 高次モードビームとして, Fig. 2 に示す素子ビーム配置と Fig. 2 (c)の位相分布に基 づく光フェーズドアレイ出力とした，また，今後の実験 検証を想定し，伝搬路は距離 $1 \mathrm{~km}$ の水平パスとした

大気構造定数 $C_{n}^{2}=1.0 \times 10^{-12} \mathrm{~m}^{-2 / 3}$ の場合のガウシア ンビームと高次モードビームとを伝搬させた際の受信強 度の 1000 回分の計算結果を Fig. 3 に示す.

各ビーム伝搬後の受信強度の 1000 回の計算結果の(平 均値, 標準偏差) はそれぞれ 


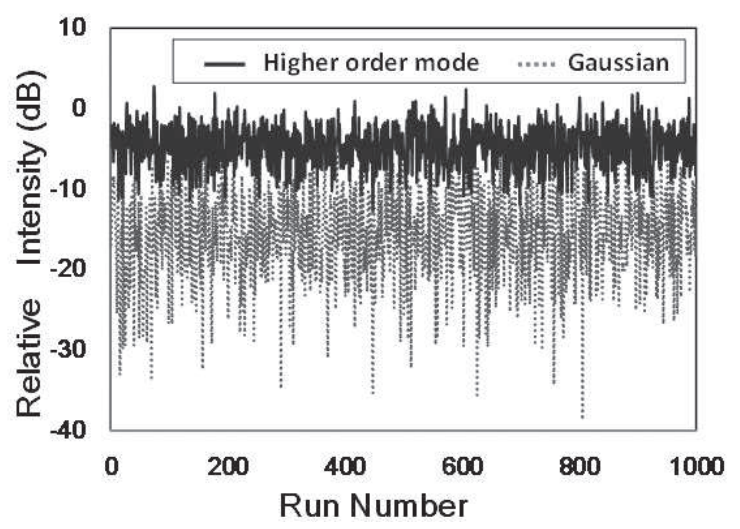

Fig. 3 Calculated results of intensity fluctuation. after $1 \mathrm{~km}$ propagation in $C_{n}^{2}=1.0 \times 10^{-12} \mathrm{~m}^{-2 / 3}$.

ガウシアンビーム : $(-15.6 \mathrm{~dB}, 5.4 \mathrm{~dB})$

高次モードビーム : $(-4.7 \mathrm{~dB}, 2.6 \mathrm{~dB})$

であり，高次モードビームが伝搬損失，ばらつきをとも

に低減する特性を有していることが分かる。

Fig. 4 に高次モード伝搬光の大気構造定数依存性を示 す(等位相分布のコヒーレント合成光と比較).

大気摇らぎが大きいほど高次モード伝搬による受信強 度変動の低減効果が有効であると示唆される。

\section{5. 光フェーズドアレイによる光空間通信}

ここでは光フェーズドアレイを用いた光空間通信の実 証実験を示す. Fig. 5 に 2 素子の光フェーズドアレイに よる実験セットアップを示す。素子間位相同期用の基準 光源 (Master Laser: $\left.\lambda_{0}\right)$ とデータ信号 $(2.8 \mathrm{Gbps}, \mathrm{OOK}(\mathrm{ON}$

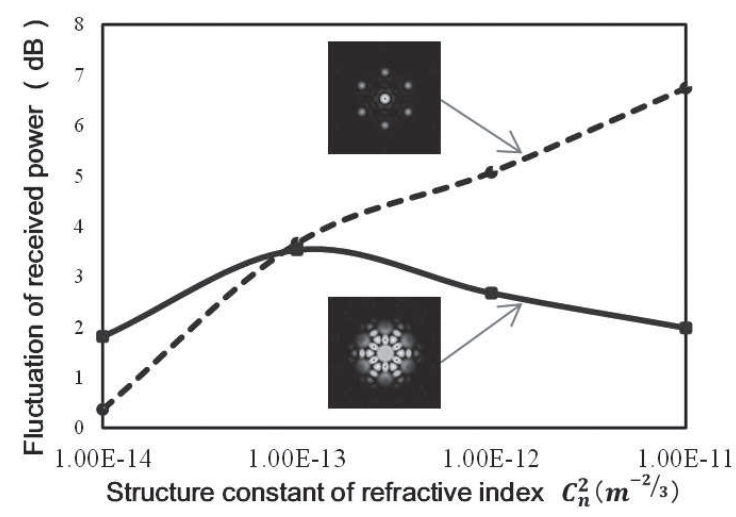

Fig. 4 Fluctuation of propagated optical intensity depending on atmospheric structure coefficient.

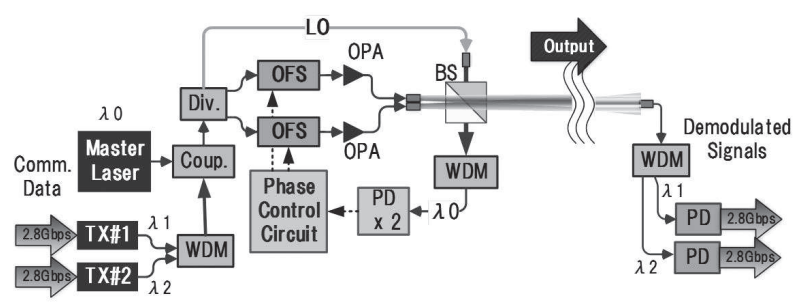

Fig.5 Experimental setup of free-space optical communication using optical phased transmitter.
- OFF Keying)) を重畳した信号伝送光の 2 波 (Tx\#1: $\left.\lambda_{1}\right)$, (Tx\#2: $\left.\lambda_{2}\right)$ とを波長多重カプラ (WDM) にて合波する. 合波した光を局発光路と 2 つ信号光路とに分岐する. 信号光路では位相制御用の光周波数シフタ $(\mathrm{OFS})$ を介し て光増幅器 (OPA)にて増幅し，コリメータで空間出力す る。一方, 局発光路では, コリメー夕にて空間出力し, 信号光と BS にて合波する。合波後, WDMにて $\lambda_{0}$ のみ を透過させ，へテロダイン検波を行う．これにより，デー 夕信号が重䪶されていない $\lambda_{0}$ 光のへテロダイン検波信 号から素子間位相誤差を検出することができる。検出し た位相誤差信号は位相制御回路を介して OFS にフィー ドバックすることで，素子間の光位相同期が実現される。

また，空間出力した 2 素子信号光は空間伝播後，コリ メータにて受信し，復調信号を波長多重カプラ(WDM) により $\lambda_{1}$ と $\lambda_{2}$ とに分岐後, 各々フォトダイオード $(\mathrm{PD})$ にてモニタする.

Fig. 6 に実証実験結果として，遠方界パターンと復調 信号とを (a) 光位相同期前 (Free-running) と (b) 光位相同 期後に対して示す。光位相同期後の遠方界パターンに 2 素子の干渉パターンが得られ，素子間位相同期が確立し ていることがわかる。また光位相同期後の復調信号にア イの開口が確認される。さらに波長多重した 2 系統の空 間通信信号が同期していることから $5.6 \mathrm{Gbps}$ の伝送が 実現できていることが分かる.

\section{6. おわりに}

将来の光フィーダリンク適用に向けた光フェーズドア レイを用いた光空間通信技術の予備検討を行った光

(a)

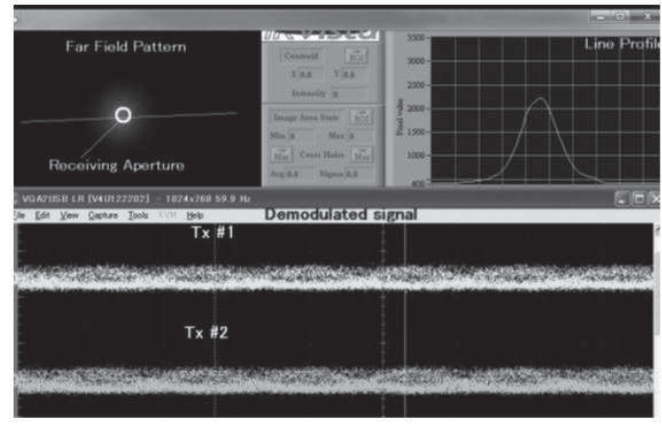

(b)

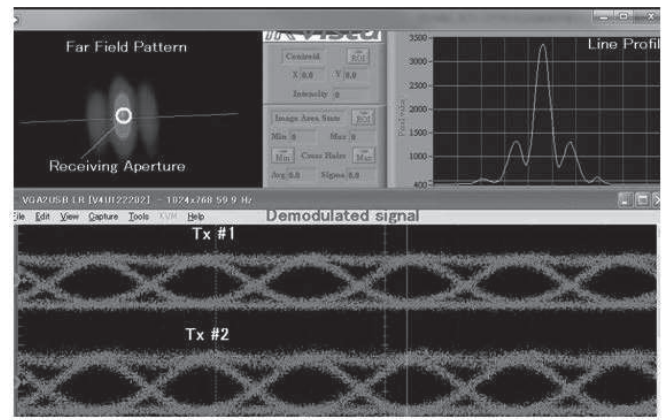

Fig. 6 Experimental data of free-space optical communication using optical phased array transmitter. (a) Before phase locking (freerunning), (b) After phase locking of optical phased array. 
フェーズドアレイにより発生させた高次モード光の大気 摇らぎ伝搬特性を計算した結果, 高次モードビームが伝 搬損失，ばらつきをともに低減する特性を有しているこ とが分かった。空間光伝搬による実験実証や高次モード ビームの位相分布のパラメータ最適化などが今後の検討 課題である。また，2素子フェーズドアレイを用いた光 空間通信実験では，素子間位相同期により，波長多重し た 2 系統の光空間通信の同期動作による5.6 Gbps 伝送 と，ビーム指向角制御とを両立できることが分かった。

\section{参考文献}

1) H. Hauschildt, F. Garat, H. Greus, K. Kably, J.-P. Lejault, H. L. Moeller, A. Murrell, J. Perdigues, M. Witting, B. Theelen, M. Wiegand, and A. Hegyi: Proc. ICSOS 2014 (2014) S1-3.

2) E. Luzhansky, B. Edwards, D. Israel, D. Cornwell, J. Staren, N. Cummings, T. Roberts, and R. Patschke: Proc. SPIE 9739 (2016) 97390C.
3) 山本 静夫, 高畑 博樹: 第 25 回 科学技術 - 学術審議会宇宙 開発利用部会 (2016) 資料 $25-1$.

4)E. Fischer, Th. Berkefeld, M. Feriencik, M. Feriencik, V. Kaltenbach, D. Soltau, P. Adolph, R. Czichy, J. Kunde, F. Heine, K. Saucke, R. Meyer, I. Richter, and Z. Sodnik: Proc. ICSO 2016 (2016) 105623K-1.

5) E. Lutz: Int. J. Satellite. Commun. Netw. 34 (2016) 461

6) A. Mody and E. Gonzalez: Proc. IEEE ICSOS 2017 (2017) 288.

7) T. Ando, E. Haraguchi, T. Sugihara, J. Suzuki, K. Kodeki, and T. Araki: Proc. IEEE International Conference on Space Optical Systems and Applications 2014 (2014) p. 6.

8) 安藤 俊行, 原口 英介, 鈴木二郎, 荒木 智宏 : 第 57 回宇宙 科学連合講演会, 鳥取 (2013) 3B11.

9) 安藤 俊行, 原口 英介, 鈴木二郎, 荒木 智宏：レーザー研 究 44 (2016) 52.

10) 安藤 俊行, 原口 英介, 鈴木二郎, 遠藤 貴雄：第 59 回宇宙 科学連合講演会 (2015) 3F06.

11) K. Saucke, C. Seiter, F. Heine, M. Gregory, D. Tröndle, E. Fischer, T. Berkefeld, M. Feriencik, M. Feriencik, I. Richter, and R. Meyer: Proc. SPIE 9739 (2016) 973906.

12) J. Surof, J. Poliak, and R. M. Calvo: Opt Lett. 42 (2017) 2173.

13) 白井 智宏：光学 34 (2005) 581 . 